\title{
ENERGY IN THE DEVELOPMENT STRATEGY OF INDIAN HOUSEHOLDS - THE MISSING HALF
}

B. Sudhakara Reddy and Hippu Salk Kristle Nathan

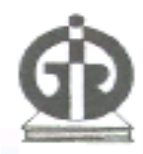

Indira Gandhi Institute of Development Research, Mumbai January 2012 http://www.igidr.ac.in/pdf/publication/WP-2012-003.pdf 


\title{
ENERGY IN THE DEVELOPMENT STRATEGY OF INDIAN HOUSEHOLDS - THE MISSING HALF
}

\author{
B. Sudhakara Reddy and Hippu Salk Kristle Nathan \\ Indira Gandhi Institute of Development Research (IGIDR) \\ General Arun Kumar Vaidya Marg \\ Goregaon (E), Mumbai- 400065, INDIA \\ Email (corresponding author): $\quad$ sreddy@igidr.ac.in
}

\begin{abstract}
There is a growing consensus that universalisation of modern energy services is central to reducing major elements of poverty and hunger, increasing literacy and education, and improving health care, employment opportunities, and lives of women and children. In India, more than 700 million people lack access to modern energy services for lighting, cooking, water pumping and other productive purposes. Without these services people-most often women-are forced to spend significant amount of their time and energy on subsistence activities. This acts as a barrier to the gender development. Although the links between gender, poverty and energy have been studied by many authors, not many have come out with practical solutions. The present paper explores the nexus between gender-energy-poverty, highlights areas of gender concern, and suggests actions. We analyse how women from rural areas and low income households are at the receiving ends of energy poverty. We then analyse the roles of different stakeholders in universalizing modern energy services with specific emphasis to women. We argue how women self help groups can be a vital link in large scale diffusion of energy efficient and renewable technologies. The paper concludes with policy prescriptions of sustainable development and gender empowerment through energy solutions.
\end{abstract}

\section{Keywords:}

Development, Energy, Environment, Gender

\section{JEL Code:}

Q4, L94, L95, L98

Acknowledgements: 


\title{
ENERGY IN THE DEVELOPMENT STRATEGY OF INDIAN HOUSEHOLDS - THE MISSING HALF
}

\author{
B. Sudhakara Reddy and Hippu Salk Kristle Nathan \\ Indira Gandhi Institute of Development Research \\ Goregaon (E), Mumbai 400 065, INDIA \\ Tel: +91-22-28416526; Fax: +91-22-28416399 \\ e-mail address: sreddy@igidr.ac.in
}

\begin{abstract}
There is a growing consensus that universalisation of modern energy services is central to reducing major elements of poverty and hunger, increasing literacy and education, and improving health care, employment opportunities, and lives of women and children. In India, more than 700 million people lack access to modern energy services for lighting, cooking, water pumping and other productive purposes. Without these services people - most often womenare forced to spend significant amount of their time and energy on subsistence activities. This acts as a barrier to the gender development. Although the links between gender, poverty and energy have been studied by many authors, not many have come out with practical solutions. The present paper explores the nexus between gender-energy-poverty, highlights areas of gender concern, and suggests actions. We analyse how women from rural areas and low income households are at the receiving ends of energy poverty. We then analyse the roles of different stakeholders in universalizing modern energy services with specific emphasis to women. We argue how women self help groups can be a vital link in large scale diffusion of energy efficient and renewable technologies. The paper concludes with policy prescriptions of sustainable development and gender empowerment through energy solutions.
\end{abstract}

Key words: Development, Energy, Environment, Gender

JEL codes: Q4, L94, L95, L98 


\section{INTRODUCTION}

Energy drives all economies - developed and developing ones. The need for energy is more pronounced in developing countries as these countries, because of low per capita energy use, tend to have low life expectancy, high infant mortality and low literacy (UNDP, 2000; Reddy, 2002). It is not just about 'quantum' of energy alone; the 'quality' of energy service also affects the standard of living. The poor households not only use small amounts of energy, but also rely on lower quality fuels such as animal dung, agricultural waste and fuel wood. Reliance on these fuels limits the amount of service that can be obtained and affects gender ${ }^{1}$ adversely (Najam and Cleveland, 2003; Rouse, 2004). The developing countries not only show low level of development, but also high degree of inequality among men and women.

Use of modern energy services and gender empowerment are complementary to each other. Energy activities influence the status of women and in turn get influenced by them. Access to clean energy services improve women's social, economic and political status-reducing the time and effort involved in household chores, providing better health and educational conditions, expanding income-generating opportunities, and easing their participation in public affairs (UNDP, 2006). At the same time, greater sensitivity to gender issues increases the effectiveness of energy programmes and policies, as well as other types of development activities that involve energy use, by ensuring that the needs and concerns of both men and women are taken into account.

In the context of gender and energy, household energy has high importance. In India, households account for $40 \%$ of direct energy use (taking commercial and non commercial energy together) and influences $70 \%$ of the total energy use (considering the energy required for goods and services consumed by households) in India (Pachauri, 2009). However, the importance of energy consumption in household sector goes beyond statistics. The pattern of household energy consumption represents stage of economic development of the family and the state of the women welfare. All household-related activities are women-centric. Energy related activities in households are no exception. Since, typically women get involved in household chore including biomass collection and cooking, the energy situation can affect women positively and negatively. Because of their socially determined roles, women assume a higher proportion of the burden of low quality fuel use and the resulting energy services. Greater access to modern energy services can provide significant social, economic and psychological benefits, especially for women and girls in developing countries, who are the primary providers and users of traditional fuels such as wood, dung and charcoal (UNDP, 2001). As the economy develops, energy consumption increases with increased use in energy appliances induced through changing lifestyles. Simultaneously, households shift to efficient technologies. Income, education, occupation and location play an important role in fuel/technology shifts. The shift towards modern energy services which are more user friendly leads to improvement of the household in social ladder, particularly for the women of the family. Moreover, women are the first and foremost victims of inappropriate fuel choice, method of collection, and inefficient technology adoption.

${ }^{1}$ Gender can mean either man or woman. Gender is defined in social context and its manifestations and implications differ across societies and cultures (Wiltshire, 1995). However, in this paper, gender refers to female. 
Even though gender issues have come to the forefront sectors like agriculture, forestry, and water, energy have been slow in acknowledging the links between gender, energy, and development. Policy makers have largely ignored the role women play in traditional energy systems. There is a lack of gender concern in National-level energy policies. The 11th five-year plan (2007-2012) expects to invest more than $\$ 100$ billion in the energy sector, including coal, oil, hydropower and other renewables and nuclear-but less than $2 \%$ of this may go towards alleviating the drudgery suffered by women and children (IRADe, 2009). Hence, it is important to contextualize household energy consumption patterns with respect to gender concerns in order to formulate policies for promotion of sustainable gender empowerment through energy solutions.

This paper aims to study the issue by analysing household energy consumption and the gender roles. The next section highlights the importance of women in the society in general, and in the context of energy in particular. The following section analyses the trends in household energy use in India and what it means to women. It looks into the availability and affordability of modern energy services among various sections of the society in urban and rural households. Next, the scheme to universalize basic energy services with specific emphasis on roles of women is examined. The paper concludes with sustainable energy security strategy which would achieve gender empowerment as an important byproduct.

\section{GENDER MATTERS}

There is a positive relationship between gender empowerment and development. Societies which have emphasized on female health care and where there is a higher participation of women in education and workforce have evidenced higher economic growth and development (Nathan et al, 2009). It is also found that developed countries have shown reduced gender inequality and improved status of women which brings about greater macro-economic stability, whereas women's relative lack of opportunities in developing and least developed countries inhibits economic growth (Stotsky, 2006).

Gender inequality manifests as hierarchical genders relations, with men above women, and women being regarded as inferior and less valuable solely by virtue of their sex. Gender hierarchy is manifested in family relationships, inheritance laws and customs; valuations of women's work and its general invisibility; and the power to make decisions in society, the family, work place, religious and other cultural institutions (Mikkola, 2005). For generations, women have been denied access to resources of their own and thereby tend to be regarded as economic dependents. Societies have been characterised by marked son preference and discrimination against daughters from the early years of life. Gender inequalities in education, excess levels of female to male mortality and higher numbers of men to women in the overall population than is considered 'standard' is common in many societies (Kabeer, 2003). This is apparent in the relative opportunities available to women and girls for development, education, health and nutrition. Such hierarchy is generally accepted by both genders, and it is not normally questioned within its cultural context.

According to Lagerlöf (2003) gender equality contributed significantly to the economic development in Europe achieved for the past 2000 years. The gender differences in the countries 
can be traced back to cultural and religious roots. ${ }^{2}$ It important that earnings and resource ownership is essential to make economic choices which allow women to move forward in time. That is why progressive thinkers advised external employment for women.

The importance of women as key drivers of development in environment and energy needs to get the attention it deserves (UNDP, 2007). Women suffer the daily drudgery of an 'un-mechanised' life, spending the bulk of each day performing basic manual tasks, including hauling fuel wood and heavy containers of water, often whilst caring for small children. Reduced drudgery for women and increased access to nonpolluting power for lighting, cooking, and other household and productive purposes can have dramatic effects on women's levels of education, literacy, nutrition, health, economic opportunities and involvement in community activities (UNDP, 2001). Gender sensitive energy policies not only bring in equity and efficiency in daily life, but also alleviate poverty and ensure achievement of all millennium development goals (MDGs). For its successful implementation, the energy sector policy, like policies in other sectors, needs to be supported by programmes for gender equality and social relations and enacted through appropriate institutions at the micro- and macro- levels (IRADe, 2009).

\section{HOUSEHOLD ENERGY CONSUMPTION -VIEWING THROUGH GENDER LENS}

\subsection{Trends in household energy consumption-urbanization, income, fuel shifts and efficiency of utilization}

Considerable changes occurred in the Indian household sector over several decades in the use of energy-consuming devices and in the behaviour of energy users. In terms of the total, the population has tripled during 1950-2005, whereas energy use in households has doubled during the same time period (Table 1). The increase in energy use can be attributed to natural increase due to population growth and increase in economic activity and development. At the same time, there has been a progressive movement towards modern energy carriers, which are more efficient. ${ }^{3}$ Therefore, in spite of increased energy-related activities, per capita energy consumption has declined. Nevertheless, the share of traditional use of biofuels (such as fuelwood, dung, etc.) for cooking and heating is still far larger than the amount used for modern applications like refrigeration, air conditioning, etc.

Table 2 gives the fuel use for cooking and lighting for urban and rural areas for different income groups. ${ }^{4}$ While urban households have adequate fuel supplies and access to LPG and electricity, many rural areas still suffer from fuel shortages. As per NSSO (2007), 90\% of rural households

\footnotetext{
${ }^{2}$ The spread of Christianity might be the main reason for gender development in the western world. Unlike the Hindu society, the early Christians improved the status of widows allowing them to keep her husband's estate and extended women's rights to inherit and hold property. Christian women also got married at a late age unlike in Hindu society where child marriages and Sati Sahagamana (a religious funeral practice among some Hindu communities in which a recently widowed woman would have immolated herself on her husband's funeral pyre) were common till the nineteenth century.

${ }^{3}$ The efficiency of utilization of energy devices for biofuel, kerosene, LPG, and electricity electricity are typically, $10 \%, 40 \%, 70 \%$, and $75 \%$ respectively (Reddy et al, 2009).

${ }^{4}$ Low, middle and high-income groups are calculated on the basis of Monthly Per Capita Expenditure (MPCE) as given in NSSO (2007) It is assumed that MPCE less than Rs. 410, in between Rs 410 to Rs 890 and higher than Rs 890 are considered as lower, middle and high income categories for rural areas and the corresponding figure for urban area are less than Rs 675, in between Rs 675 and Rs 1880, and more than Rs 1880.All values in Rs. Per household.
} 
do not use clean cooking fuels and $45 \%$ of them do not have access to electricity. The corresponding figures for urban area are $33 \%$ and $7.8 \%$ respectively. This large urban rural divide in household energy use can be attributed to non-uniform availability of resources or uneven access to infrastructure to avail the resources. However, energy availability is part of the story. Any energy carrier, in order to be used in a household, needs to be affordable. For poor households, energy forms a significant portion of their monthly expenses, and they do not use commercial fuels as they cannot afford for the same. High-income households have a greater choice in selecting an energy carrier and many opt for cleaner, comfortable and more efficient modern energy carriers such as electricity or LPG (Reddy and Srinivas, 2009). So, as evident from Table 2, as one moves down from urban rich to rural poor there is an increased dependency on energy carriers, which are traditional, inefficient, and cause miseries to women as explained in the next section.

\subsection{Women's invisible time and effort}

The traditional form of energy (bio fuels), which dominate the energy spectrum, is different from its counterparts such as kerosene, LPG, or electricity in one respect. Unlike others, the preparation (collection, transportation, cutting, etc.) of bio fuel is done by the households themselves. Women, being the primary cook in the household, by default are given the responsibility of fuel collection, preparation as a cooking-related activity and water fetching (Table 3). Women are assisted by girl children of the family in this regard. A typical day of a rural household begins at the break of dawn with women and children walking distances to collect wood and other bio fuels and process them for firing in their traditional stoves.

Even in the twenty first century, bio fuels still prevail in rural households and so is the drudgery of women. Moreover, this family labor provided by women is unpaid and thereby it does not enter the market system and hence women are not credited for their true contributions. Since the time spent by women on these survival tasks is largely invisible, it does not enter into the reporting of energy patterns and statistics. For example, while the energy used by an electric pump for water pumping can be easily measured and reported, the energy expended by a woman fetching water goes unmeasured, unmonetized, and unrecorded in energy statistics. Trucks that transport fuels are a part of market mechanisms whereas the energy of women head-loading the same is excluded (Cecelski, 2000). ESMAP energy survey of Indian rural households in 1996 (ESMAP, 2004) have accounted the time spent by different households in cooking and fuel collection activities. Occupational background influences the time spent in collection of fuel for cooking. Labour households, who are the poorest among the lot, spend maximum time in collection irrespective of the type of fuel they use for cooking. The lives of the relatively rich households are little better than the poor households as in the professional families spend 10 to $20 \%$ of the core cooking time in fuel collection where as women in laborers' family spend about 20 to $40 \%$ of the time in collection. These responsibilities often constrain their capacity to undertake other employment activities.

As IRADe (2009) observes together, women and children collect close to $28 \%$ of all primary energy. However, no inputs in terms of investment, management or technology are provided to them-something that all other energy sectors take for granted. The most important motivation factor behind the use of bio fuels (wood, cow dung and crop residue) is that its direct cost is almost zero. The opportunity cost, in terms of time spent by women, is not taken into account by households which consider women to be free and fit for such activities. Had the traditional fuels 
born tangible costs, and had the male community had to involve in the procurement of such fuels, the households would have long abandoned these traditional fuels, and moved to higher versions.

\subsection{Impact on health and education of women}

The use of traditional biomass fuels does not limit the drudgery of women to the back bending job of collection and transportation of the fuel, but also its use. The typical efficiency of biomass stove is $10 \%$ which indicate how inefficiently the hard earned energy is used. Due to inefficient use, these fuels, when burnt, give off significant quantities of smoke and particulates which have adverse effect on health of women and girl children. The indoor air pollution level, i.e., mean 24 hr RSPM concentration has been shown in Fig. 1. The exposure levels for the wood and mixed fuel users range from about 400 to 700 micrograms per cubic meter of air. As a comparison, the Environmental Protection Agency of the United States recommends average exposures to be no greater than 50 micrograms per cubic meter of air (Barnes, and Sen, 2004).

Another aspect of this health impact is that it is 'invisible'. Since the indoor air pollution acts as a slow poison in the kitchen and affects the health of women, who are at the bottom of the family health priority, these impacts are considered unavoidable yet unnoticeable. Inefficient fuels coupled with inefficient stoves have prolonged cooking, which in turn makes longer exposure to harmful smoke detrimentally impacting women's health. Children also get exposed to these pollutants more often as they often play in the proximity of their mothers. In this regard, improved stoves have multiple advantages. It not only reduces the cooking time, but also uses less fuel; so in turn saves money and reduces the drudgery of colleting fuel. Also improved stove in quite a few cases have a chimney, which reduces the exposure to cooking smoke.

According to an IGIDR study (Laxmi et al, 2003) the health impacts of the use of bio-fuels are quite high for adult women. The losses incurred because of cooking fuels, including work days spent, expenditure on illness and lost working days due to illness are Rs. 29 billion per year in the rural areas of Rajasthan. Smith (2000) has indicated that high risks such as respiratory infections (ARI), chronic obstructive pulmonary disease (COPD), lung cancer and also tuberculosis (TB), asthma, and blindness are prevalent in India on account of indoor air pollution. Conservative estimates indicate that some 400-550 thousand premature deaths can be attributed annually to use of biomass fuels in these population groups. Using a disability-adjusted lost life-year approach, the total is $4-6 \%$ of the Indian national burden of disease, placing indoor air pollution as a major risk factor in the country. As per World Health Organization (WHO), indoor air pollution which is referred to as 'killer in the kitchen' is responsible for 1.6 million deaths per year, i.e., one life is lost in every 20 seconds (UNDP, 2007).

In addressing energy poverty it is crucial to understand and deal with the gender dimension. UNDP (2001) reports reveal that when women are overburdened, they are more likely to keep their daughters at home and away from school to assist with household activities, including fuel and water collection, thereby limiting opportunities for girls to move forward through education, thus increasing the likelihood that their families will remain in poverty. Education and literacy levels are positively correlated with decreases in fertility rates. Women, with more education, tend to have fewer children, and to be better able to care for them. The fuel-related burdens experienced by women in developing countries hinder social and economic progress throughout 
the community and have long-lasting impacts when personal and social development opportunities are lost.

\section{CLIMBING THE DEVELOPMENT LADDER}

One of the major components of energy choice of a household relates to the status of technology it uses. Irrespective of the quantum of energy flowing through various stages of the energy cycle, technology is an important driver of efficiencies, costs and prices, as well as the pattern of consumption of energy in an economic system. Since technological changes have a significant impact on the energy use, any future plans for the energy sector and its role in an economic system must take into account the technology progress. At the consumption end of the cycle, we have to understand that the demand for energy is basically a derived demand, which depends on factors such as prices of energy and the cost of energy using device, availability of these energy technologies, incomes of consumers, and energy perceptions in the households.

In this context the status of the women in the family matters. In the households and communities where women labor is discounted and home making is considered as a soft, free, and leisurely work, there the energy decisions are not consistent with the comforts of women. This is one such example of dichotomy where activities are women-centric, but decisions remain with men. ${ }^{5}$ Slight improvement in energy technology can have significant improvement in the standard of lives for women. For instance, let us consider the case of lighting.

Good lighting acts a facilitator in household activities. Availability of lighting increases the productive hours in the household. Very poor quality lighting or no lighting makes the women, who are the main managers of household activities to depend heavily on daylight hours. Also the poor quality of lighting, do not provide women who confine themselves to the four walls of house to read or do any close work. As per UNDP (2001), Global evidence has shown that the availability of illumination in the home increases female educational attainment and literacy and extends the working day of women to include income-generating opportunities such as in cottage industry. Lighting in public places also increases the safety of women and communities and allows women greater access to public gatherings.

From the perspective of the households, the shift from low to high efficiency fuels/technologies increases the standards of comfort, cleanliness, and convenience. The increased possession of modern carriers becomes a symbol of status and success. In the consumer society, the consumer's self-respect depends strongly on his/her level of possession of these goods and the fuel/technology shift from the lower to higher order satisfies his/ her ego. However, there is little agreement on specific goals and the strategies to attain these benefits when we consider gender issues. Technology can be savior to women time and drudgery, to which the male counterparts put a blind eye. It is not only about providing cooking fuel that is demanding in terms of women's energy and time, there are a whole range of tasks on which the household is dependent for its survival, such as water provision and food processing.

Traditional fuel use has cumulative impacts cause and effects which keep women voiceless, uneducated, weak, and disempowered (Fig 2). Much of this drudgery could easily be reduced by

\footnotetext{
${ }^{5}$ Another such example is decision related to fertility i.e. child bearing and birth.
} 
the application of modern energy forms and efficient utilization of biofuels such as biogas (Table 4).

Modern energy services have a great potential to contribute to gender equity so that women and men benefit fairly from access to these services (Table 5). Access to modern energy services result in positive impacts such as: freeing the woman's time from domestic tasks, enabling access to educational media and communications in schools and at home, mitigating the impacts of indoor air pollution on women, allowing access to better medical facilities for maternal care including refrigeration and sterilization, and enhancing income generation activities (Clancy et $a l, 2004)$. Energy carriers can also be considered as material assets. Therefore having access to sufficient amounts of good quality energy will make the household to climb the 'Comfort ladder' and thereby the 'Development ladder'.

\section{UNIVERSALIZATION OF MODERN ENERGY SERVICES-IMPACT ON GENDER}

Since household energy activity is women centric, energy universalization program benefits women most. Women are the forerunner in reaping the advantages of climbing the energy ladder. Moreover, women have knowledge about the fuelwood species, the smoke that comes, the cost of technologies and the prices. So energy universalization programs are not only aimed 'for' women welfare, but also need to be spearheaded 'by' women. However, unfortunately under India's family system, women are hardly consulted in choosing a fuel or technology.

In the model of energy universalization program, here we revisit the EMPOWERS (Entrepreneurship-based Model for Provision Of Wholesome Energy related basic Services) model as proposed by Reddy et al (2009). The three actors in this model, viz. the entrepreneurs, NGOs, and consumers can be inducted into the self help group (SHG) structure. Before going into the model, let us be briefed about SHG.

Self-Help Group (SHG) is a small voluntary association of poor people, typically constituting 10 to 20 women, preferably from the same socioeconomic background, who come together for the purpose of solving their common problems through self-help and mutual help (Ghadoliya, 2004). They are typically a three level stricture (see Fig 3). The lowest level is the individual SHGs. Typically, about 15 to 50 SHGs make up to form a 'SHG Cluster' with either one or two representatives from each SHG. Depending on the civic and geography situation, several clusters are made up to form a SHG federation (Reddy and Manak, 2005). ${ }^{6}$

The SHG promotes small savings among its members, which are kept with a bank, which in turn provides loan which is lent to SHG member(s). In short, SHG operates as savings-first business model whereby the member's savings are used to fund loans (Reddy and Manak, 2005). SHGs have a phenomenal growth in India, the number grew at an average annual growth rate of $82 \%$ during 1993-2006, and the credit amount grew at a rate of 110\% (Fouillet and Augsburg, 2007). The major program is the SHG-bank linkage program which was initiated by National Bank for Agriculture and Rural Development (NABARD) in 1992, and by the financial year 2005-06, the program covered more than 6,20,000 SHGs, incorporating more than nine million households

\footnotetext{
${ }^{6}$ The dependence on geography can be of exemplified as a fishing community spread across several coastal villages can form one federation. Similarly a tribal community in different contiguous hamlets of mountainous locality can form a federation. From civil structure perspective, villages under a particular mandal can form a federation.
} 
with more than 90\% women members and 95\% on-time repayment of loans (Tankha, 2002; Fouillet and Augsburg, 2007). SHGs have clearly succeeded in India in terms of developing women community life, providing them with some degree of financial independence, and empowering women in family decision-making.

In the proposed EMPOWERS model, participation of three actors, consumers, entrepreneurs, and NGOs can be channelized through the SHG structure (Fig 4). The mapping is given as follows:

SHG: Individual SHG groups can act as consumers thereby avoiding multiple individual contacts. Since energy services are women-centric, it is expected that SHGs will approve such services. Provision of services in a group facilitates delivery of services and collection of bills. Also, in the form of SHG, consumers would take care of the any common public property like biogas connection networks.

SHG cluster: SHG clusters are typically at village-level and constitute several SHGs. With already linked to the banks, SHG cluster can act as entrepreneurs and can initiate energy projects in the community through soft loans from financial institutions. SHG cluster would form the central role in EMPOWERS model. For the government and policy makers point of view, SHG clusters would be the diffusion targets and not millions of "end-users". These clusters can market energy-efficient devices. Through this entrepreneurial scheme, SHG cluster can strengthen its financial base. These are expected to be successful because of good understanding of consumer needs and environment.

SHG federation: SHG federations can do the role of the NGO, which can get itself trained in providing modern energy services, spread the awareness on multitude benefits of such services, and do capacity building exercises. Energy solutions triggered through SHG federations will succeed as they constitute the homemakers, who are the victim of energy-drudgeries. Moreover, they can understand the benefit most as they themselves are the benefactors. Since the victim and benefactors and the decision-making body is one and the same under a SHG structure, the decisions would be towards promoting modern energy services. Financial institutions and civic bodies, with already established rapport with the SHG federations can facilitate such projects.

One must note, that in household energy management, women experience constraints and stimuli; have abilities and weaknesses; and hold rights, responsibilities and obligations. Hence they can optimize on households benefits and costs once they are allowed to participate in decision making. Hence, government can aim to induct more women in decision bodies of financial institutions, utilities and in other government institutions dealing with energy solutions. In case of energy management, the buck needs to stop at women, who can instrument energy universalization a reality.

\section{GENDER, ENERGY AND SUSTANABILITY}

The present approach envisages the provision of modern energy services through biomass, wind, solar, and small-scale hydro. This offers major opportunities for income generation and livelihoods diversification, as well as fuel provision and environmental protection. It also ensures sustainability of biomass supply (for example, sustainable forest management by communities). Because of their direct involvement in obtaining energy services for the family women are 
naturally careful towards natural resource management and the environment thus decreasing the ecological foot print.

The rural households, in general, use electricity primarily for lighting and entertainment (television) and agriculture water pumping. They do not see the opportunities for making productive use of electricity. Hence there is a need for diversifying rural economic livelihoods through modern energy services. There is a lack of 'manpower' for local energy suppliers (e.g. solar-powered battery charging, micro-hydro installations with mini-grids) and the need for entrepreneurs who can supply, install and repair the energy hardware. This lack of 'manpower' can be compensated with 'women power' if SHGs steps in to the scheme of things. Given the success of SHGs, and their established rapport with different actors, the EMPOWERS model with SHG federation, SHG cluster, and individual SHG groups undertaking the roles of capacity builders, entrepreneurs, and consumers respectively. SHG driven EMPOWERS model is more likely to be successful, replicable, and sustainable.

Availability of mechanical and process heat technologies can be a stimulus to the start up of various small-scale industry enterprises (sawing, food processing etc) as well as service enterprises such as hairdressing, photocopying and internet café. Operating a grain mills can also be a womens' domain, since they improve product quality as well as reducing women's labour. In general, women-headed enterprises are located in the home, and these 'cottage industries' have low rates of return which prevent inward investment, hindering innovation and expansion which are regarded as key factors in enterprise sustainability (Grosh and Somolekae, 1996). Access to resources (such as credit, land and education, which are recognised as key factors in microenterprise development) will make such industries sustainable. Once the resources area available, women begin to take decisions on their own, at the home front, such as observing family planning practices and providing education to the girl child. Educated women are likely to take outside employment rather than stay home with children. Education enables them to have late marriages which can result in fewer children. This also increases self image of women (e.g. self-esteem, capacities in development activities, knowledge and skills).

Women's access to decision-making within the household and community will increase their ability to influence processes and resource allocation. Given the disproportionate number of poor women in rural areas such decision-making could make a significant contribution to the development of gender-equitable sustainable livelihoods.

\section{CONCLUSIONS-THE WAY AHEAD}

The nexus between poverty, energy, health, education and gender empowerment have been discussed in this paper. The situation with women is like having "responsibility without authority". It is the responsibility of women to collect the fuel, carry, process, and use it; without having a say in the choice of fuel, the usage method, and the technology adoption. These arduous tasks not only reduce the time available to contribute to other aspects of livelihood strategies, but also, affect women's health. Along with collection and transportation, cooking in unventilated kitchen has its own specific impacts. Low- and middle-income groups in rural areas and lowincome groups from urban regions are the main users of the biofuels (largely fuel wood). Most of these fuels are collected by women and children who carry loads of fuel wood, sometimes covering as far as five kilometers. Their lower status in a largely patriarchal society renders them 
ideal candidates for this back-breaking, time-consuming, and in many cases unhealthy but essential 'survival work'. This 'hard earned' energy is used very inefficiently, converting only about 10 per cent of the total into useful energy. The linkage between poverty, living conditions, livelihoods, and the way energy is used is clear from various observations made in this paper.

In developing countries like India, the potential for demand reduction is often even larger. Energy needs in India are different from those of the West because of differences in the requirement of energy services, e.g., space heating is important in the West whereas satisfaction of basic human needs such as cooking and lighting are of paramount importance in India. The poor often do not have access to efficient fuel/technology and depend on their own labour, on animal power or fuel wood, and other types of biomass, which have a high price in terms of human time and labour. They also have health and gender impacts, which are usually more severe on women. Hence "climbing of development ladder" (wood stove $\rightarrow$ efficient wood stove $\rightarrow$ LPG stove and/or electric hot plate $\rightarrow$ increased leisure time $\rightarrow$ increased income). It means addressing energy development, poverty, social justice, equity and gender issues as parts of the same political process of development. It involves bridging the gap between changing attitudes and environmental degradation and the patterns in the use and reuse of the earth's resources. This should be the strategy that could have positive impact not only on the quality of life but also on the resources and the environment.

The Indian household energy problem is not primarily a problem of the scarcity of energy per se, but inefficient energy conversion to obtain the desired services. The consequence of such utilization is the serious health hazard of inhaling smoke from fuels used for cooking. This inefficiency of utilization is a factor behind bad health, poor education atmosphere, and the hardship imposed on women and children, etc. The gathering of fuel wood becomes more difficult as land degradation spreads. The supply of fuel wood, especially to urban areas, is a contributing factor to deforestation and land degradation. Given the magnitude of these problems and issues, the proposed solutions need to be sustainable.

To achieve this goal, we need to design new approaches by engendering the energy approach. The country wide SHG networks can be tapped for this purpose. In this paper we have proposed to integrate the SHG structure to energy solution model. SHGs at the lowest level can be energy consumers, thereby being the diffusion targets instead of millions of end users. At cluster level, SHGs can own the energy enterprise built on their own funds and supplying energy services to all the members. SHG federation can provide the necessary capacity building and establish the necessary linkages with other stakeholders like financial institutions, equipment manufacturers, utilities, and government agencies. Likewise SHGs, energy model driven by SHGs are likely to succeed because in this scheme of things, the decision makers, viz. women are the victims and benefactors.

Through the implementation of such schemes, economic efficiency and rural growth can be achieved by supplying sufficient energy at least cost to the poor. Reduced drudgery for women and increased access to nonpolluting power for lighting, cooking, and other household and productive purposes can have significant impact on women's levels of education, literacy, nutrition, health, economic opportunities and involvement in community activities. These 
improvements in women's lives can, in turn, have significant beneficial consequences for their families and communities.

\section{References}

Barnes, D. and Sen M., 2004, The Impact of Energy on Women's Lives in Rural India, World Bank Report, 276/04, Washington D.C: Word Bank.

Cecelski E., 2000, 'The Role of Women in Sustainable Energy Development', National Renewable Energy Laboratory, Colorado.

Clancy, J., Oparaocha S., and Roehr U., 2004. Gender Equity and Renewable Energies. Thematic Background Paper Presented at the International Conference on Renewable Energies, Bonn 2004.

Centre for Monitoring Indian Economy (CMIE). 2006. India's Energy Sector, New Delhi.

ESMAP (Energy Sector Management Assistance Program), 2004, The Impact of Energy on Women's Lives in Rural India, Joint study by UNDP/World Bank, January.

Fouillet, C. and Augsburg, B., 2007, 'Spread of the Self-Help Groups Banking Linkage Programme in India', Paper prepared for International Conference on Rural Finance Research: Moving Results, held by FAO and IFAD, Rome, March 19-21.

Ghadoliya, M.K., 2004, Empowering Women Through Self -Help Groups: Role Of Distance Education, in Third Pan-Commonwealth Forum 2004. Dunedin: New Zealand.

Grosh, B and Somolekae, G.1996.Mighty Oaks from Little Acorns: Can Micro Enterprise Serve as the Seedbed of Industrialization? World Development, Vol. 24, No. 12, pp. 1879-1890.

IRADe, 2009, Gender Analysis of Renewable Energy in India: Present Status, Issues, Approaches and New Initiatives, Energia, Integrated Research and Action for Development.

Kabeer, N., 2003, 'Gender inequality in educational outcomes: a household perspective', Paper commissioned for the EFA Global Monitoring Report 2003/4, The Leap to Equality", UNESCO.

Lagerlöf, N-P., 2003, Gender Equality and Long-Run Growth, Journal of Economic Growth, Vol. 8, No. 4, pp. 403-426.

Laxmi, V., Parikh J., Karmakar S., and Dabrase, P. 2003. 'Household energy, women's hardship and health impacts in rural Rajasthan, India: need for sustainable energy solutions'. Energy for Sustainable Development, Vol. 7, No. 1, pp. 50-68

Mikkola A, 2005, Role of Gender Equality in Development -A Literature Review, University of Helsinki, RUESG and HECER, Discussion Paper No. 84, November. 
Najam, A., and Cleveland, C.J., 2003, 'Energy and Sustainable Development at Global Environmental Summit: An evolving agenda'. Environment, Development and Sustainability, Vol. 5, Nos. 1-2, pp. 117-138.

Nathan, H.S.K., Mishra, S., and Rampal, P., 2009. 'Gender Development Index: Two Corrections', PP-062-19, Proceedings/Project Reports Series, Indira Gandhi Institute of Development Research (GIDR), Mumbai.

NSSO (National Sample Survey Organisation), 2007, Results of the National Sample Survey, NSSO, New Delhi.

Pachauri, S., 2009, An energy analysis of household consumption: changing patterns of direct and Indirect energy use, Netherlands: Springer.

Reddy, A.K.N., 2002, 'Energy technologies and policies for rural development'. In Johansson, T.B. and Goldemberg, J. (eds.), Energy for Sustainable Development: A Policy Agenda, pp. 115136. New York: United Nations Development Programme.

Reddy, B.S., P. Balachandra and H.S.K. Nathan, 'Universalization of access to modern energy services in Indian households-Economic and policy analysis', Energy Policy, Vol. 37, No. 11, pp. 4645-57.

Reddy, C.S. and Manak, S., 2005, 'Self-Help Groups: A Keystone of Microfinance in India Women empowerment \& social security', APMAS (Mahila Abhivruddhi Society, Andhra Pradesh), Hyderabad.

Reddy, B.S. and Srinivas, T., 'Energy Use in Indian Household Sector-An Actor-Oriented Approach', Energy-The International Journal, Vol. 34, No 6, pp. 992-1002.

Rouse, J. R. 2004, Water, Engineering and Development Centre (WEDC). Loughborough University, United Kindom, March.

Smith, K.R., 2000, 'National burden of disease in India from indoor air pollution', PNAS, Vol. 97, No. 24, pp. 13286-13293.

Stotsky, J.G. 2006, 'Gender and Its Relevance to Macroeconomic Policy: A Survey' International Monetary Fund Working Paper WP/06/233, Washington, D.C.: International Monetary Fund.

Tankha, A., 2002, 'Self-help Groups as Financial Intermediaries in India: Cost of Promotion, Sustainability and Impact', A study prepared for ICCO and Cordaid, The Netherlands, 2002.

UNDP (United Nations Development Program), 2000, World Energy Assessment: Energy and the Challenge of Sustainability, New York: UNDP. 
UNDP (United Nations Development Program), 2001, Generating opportunities, Case studies on energy and women, UNDP Sustainable Energy, 2001, New York: UNDP.

UNDP (United Nations Development Program), 2006, Fact Sheet on Energy, Gender and Sustainable Development, Energia, New York: UNDP.

UNDP (United Nations Development Program), 2007, Gender Mainstreaming, A key driver of development in environment and energy, New York: UNDP.

Wiltshire, R, 1995, 'Gender in Development: A critical issue for sustainable Development' in Steady F.C. and Toure R. (Eds) Women and the United Nations Reflections and New Horizons, Schenkman Books, Vermont: Inc. Rochestor, pp. 127-132.

World Bank, 2002, 'India: Household Energy, Indoor Air Pollution and Health.', ESMAP Report No. 261/02. Washington, D.C: World Bank. 
Table 1 Household Energy consumption (PJ) - 1950 - 2005

\begin{tabular}{|c|c|c|c|c|c|c|c|}
\hline Year & Population & 3io fuels & Kerosene & LPG & Electricity & Total & $\begin{array}{c}\text { Per capita } \\
\text { consumption }(\mathrm{GJ})\end{array}$ \\
\hline 1950 & 370 & $\begin{array}{r}2884.5 \\
(98.18)\end{array}$ & $\begin{array}{r}50.4 \\
(1.72)\end{array}$ & $\begin{array}{r}0 \\
(0.00)\end{array}$ & $\begin{array}{r}2.7 \\
(0.09)\end{array}$ & 2938 & 7.94 \\
\hline 1960 & 446 & $\begin{array}{r}3348 \\
(96.26) \\
\end{array}$ & $\begin{array}{l}124.2 \\
(3.57) \\
\end{array}$ & $\begin{array}{r}0 \\
(0.00) \\
\end{array}$ & $\begin{array}{r}5.85 \\
(0.17) \\
\end{array}$ & 3478 & 7.8 \\
\hline 1970 & 555 & $\begin{array}{r}3906 \\
(95.71)\end{array}$ & $\begin{array}{l}157.5 \\
(3.86)\end{array}$ & $\begin{array}{r}2.7 \\
(0.07)\end{array}$ & $\begin{array}{l}14.85 \\
(0.36)\end{array}$ & 4081 & 7.35 \\
\hline 1980 & 687 & $\begin{array}{l}4765.5 \\
(93.61)\end{array}$ & $\begin{array}{l}235.8 \\
(4.63)\end{array}$ & $\begin{array}{r}54 \\
(1.06)\end{array}$ & $\begin{array}{r}36 \\
(0.71)\end{array}$ & 5091 & 7.41 \\
\hline 1990 & 841 & $\begin{array}{l}5242.5 \\
(90.62)\end{array}$ & $\begin{array}{r}301.5 \\
(5.21)\end{array}$ & $\begin{array}{r}117 \\
(2.02)\end{array}$ & $\begin{array}{r}123.75 \\
(2.14)\end{array}$ & 5785 & 6.88 \\
\hline 2000 & 1012 & $\begin{array}{r}5130 \\
(85.61)\end{array}$ & $\begin{array}{r}282 \\
(4.95)\end{array}$ & $\begin{array}{r}288 \\
(5.05)\end{array}$ & $\begin{array}{r}292.5 \\
(5.13)\end{array}$ & 5700 & 6.02 \\
\hline 2005 & 1100 & $\begin{array}{r}4950 \\
(81.25)\end{array}$ & $\begin{array}{r}265 \\
(4.35)\end{array}$ & $\begin{array}{r}427 \\
(7.01)\end{array}$ & $\begin{array}{r}450 \\
(7.39)\end{array}$ & 5642 & 5.13 \\
\hline
\end{tabular}

Note: Figures in parentheses represent percentages;

Source: (CMIE, 2006) 
Table 2 Energy carrier mix for cooking and lighting for different income groups (2004-05) in urban and rural India (values show percentage share of households)

\begin{tabular}{|c|c|c|c|c|c|c|c|}
\hline \multirow[b]{2}{*}{ End use } & \multirow[b]{2}{*}{ Energy carrier } & \multicolumn{3}{|c|}{ Rural } & \multicolumn{3}{|c|}{ Urban } \\
\hline & & $\begin{array}{l}\text { Low } \\
\text { Income }\end{array}$ & $\begin{array}{l}\text { Medium } \\
\text { Income }\end{array}$ & $\begin{array}{l}\text { High } \\
\text { Income }\end{array}$ & $\begin{array}{l}\text { Low } \\
\text { Income }\end{array}$ & $\begin{array}{l}\text { Medium } \\
\text { Income }\end{array}$ & $\begin{array}{c}\text { High } \\
\text { Income }\end{array}$ \\
\hline \multirow{5}{*}{ Cooking } & Biomass & 91.28 & 85.94 & 57.55 & 52.21 & 13.02 & 1.66 \\
\hline & Kerosene & 0.59 & 1.16 & 3.40 & 11.42 & 11.12 & 4.20 \\
\hline & LPG & 0.73 & 7.65 & 33.10 & 26.46 & 67.77 & 82.00 \\
\hline & No cooking & 1.56 & 0.66 & 3.20 & 2.40 & 4.63 & 10.59 \\
\hline & Electricity/others & 5.84 & 4.59 & 2.75 & 7.51 & 3.46 & 1.55 \\
\hline \multirow{3}{*}{ Lighting } & Kerosene & 61.62 & 39.97 & 16.45 & 17.17 & 3.29 & 0.30 \\
\hline & Electricity & 37.64 & 59.43 & 83.00 & 81.82 & 96.35 & 99.25 \\
\hline & $\begin{array}{c}\text { Others (including } \\
\text { no lighting) }\end{array}$ & 0.73 & 0.60 & 0.55 & 1.00 & 0.36 & 0.45 \\
\hline \multicolumn{2}{|c|}{ Total households (Million) } & 58.58 & 71.89 & 14.46 & 25.19 & 31.56 & 6.31 \\
\hline
\end{tabular}


Table 3 Fuel use and women time allocation in its preparation and use

\begin{tabular}{|c|c|c|c|c|c|c|c|c|c|c|c|c|}
\hline \multirow[b]{2}{*}{$\begin{array}{l}\text { Type of } \\
\text { Family }\end{array}$} & \multicolumn{4}{|c|}{ Fuel wood } & \multicolumn{4}{|c|}{ Dung } & \multicolumn{4}{|c|}{ Crop residue } \\
\hline & $\begin{array}{c}\% \text { using } \\
\text { fuel }\end{array}$ & $\begin{array}{l}\text { Collection } \\
\text { fuel (hrs) }\end{array}$ & \begin{tabular}{|l|} 
Cook \\
(hrs)
\end{tabular} & $\begin{array}{c}\text { Collection as } \\
\% \text { cook hrs }\end{array}$ & $\begin{array}{c}\% \text { using } \\
\text { fuel }\end{array} \mid$ & $\begin{array}{l}\text { Collection } \\
\text { fuel (hrs) }\end{array}$ & $\begin{array}{c}\text { Cook } \\
\text { (hrs) }\end{array}$ & $\begin{array}{c}\text { Collection as } \\
\% \text { cook hrs }\end{array}$ & $\left|\begin{array}{c}\% \text { using } \\
\text { fuel }\end{array}\right|$ & $\begin{array}{l}\text { Collection } \\
\text { fuel (hrs) }\end{array}$ & $\begin{array}{l}\text { Cook } \\
\text { (hrs) }\end{array}$ & $\begin{array}{c}\text { Collection as } \\
\% \text { cook hrs }\end{array}$ \\
\hline Professional* & 61 & 0.5 & 2.79 & 18 & 53 & 0.4 & 2.98 & 13 & 24 & 0.41 & 3.15 & 13 \\
\hline Large Farmers & 81 & 0.67 & 2.53 & 26 & 66 & 0.7 & 2.52 & 28 & 31 & 0.53 & 2.57 & 21 \\
\hline Small Farmers & 78 & 0.92 & 2.58 & 36 & 55 & 0.78 & 2.85 & 27 & 26 & 0.44 & 3.12 & 14 \\
\hline $\begin{array}{l}\text { Artisans and } \\
\text { Laborers }\end{array}$ & 60 & 1.08 & 2.56 & 42 & 58 & 0.77 & 2.91 & 26 & 45 & 0.65 & 3.07 & 21 \\
\hline
\end{tabular}

* They are the families in business or providing services

Source - ESMAP Energy Survey 1996 (ESMAP, 2004) 
Table 4 Modern energy option to climb on the development ladder

\begin{tabular}{|l|l|l|}
\hline Energy service needed & Current energy option & Modern energy option \\
\hline Cooking & $\begin{array}{l}\text { Bio fuels (wood, dung, } \\
\text { agriculture waste, etc.) }\end{array}$ & $\begin{array}{l}\text { Gaseous fuels (bio gas, LPG, } \\
\text { PNG etc.) }\end{array}$ \\
\hline Lighting & Kerosene & $\begin{array}{l}\text { Electricity (Grid and off- } \\
\text { grid) }\end{array}$ \\
\hline Water pumping & Manual & $\begin{array}{l}\text { Electricity (Grid and off- } \\
\text { grid) }\end{array}$ \\
\hline
\end{tabular}


Table 5 Improving the position of women through modern energy services

\begin{tabular}{|c|l|l|l|}
\hline $\begin{array}{c}\text { Modern energy } \\
\text { services }\end{array}$ & \multicolumn{1}{|c|}{ Direct Benefit } & Indirect Benefit & \multicolumn{1}{|c|}{ Strategic Benefit } \\
\hline Gas for cooking & $\begin{array}{l}\text { (i) Less time and effort in } \\
\text { gathering and carrying firewood } \\
\text { (ii) Reduce indoor air pollution } \\
\text { and improved health through } \\
\text { smokeless services }\end{array}$ & $\begin{array}{l}\text { More time for } \\
\text { productive } \\
\text { activities }\end{array}$ & $\begin{array}{l}\text { Less destruction of } \\
\text { natural forests }\end{array}$ \\
\hline $\begin{array}{c}\text { Electricity for } \\
\text { lighting }\end{array}$ & $\begin{array}{l}\text { Increase working/studying } \\
\text { hours, and improve conditions } \\
\text { during evening hours }\end{array}$ & $\begin{array}{l}\text { Increase } \\
\text { possibility of } \\
\text { activities during } \\
\text { evening and } \\
\text { night }\end{array}$ & $\begin{array}{l}\text { Make streets safer by } \\
\text { allowing } \\
\text { participation in other } \\
\text { activities (e.g. evening } \\
\text { classes and women's } \\
\text { group meetings). }\end{array}$ \\
\hline $\begin{array}{c}\text { Electricity for } \\
\text { Water pumping }\end{array}$ & $\begin{array}{l}\text { Pumped water provides better } \\
\text { hygiene and water quality. }\end{array}$ & $\begin{array}{l}\text { Reduce need for } \\
\text { haul and carry }\end{array}$ & $\begin{array}{l}\text { Better health standards, } \\
\text { check on water borne } \\
\text { diseases }\end{array}$ \\
\hline $\begin{array}{c}\text { Mills for grinding } \\
\text { and other } \\
\text { mechanical works }\end{array}$ & $\begin{array}{l}\text { Reduce the burden of rice } \\
\text { grinding at home }\end{array}$ & $\begin{array}{l}\text { Increases variety } \\
\text { of enterprises } \\
\text { and increased } \\
\text { incomes }\end{array}$ & $\begin{array}{l}\text { lllow access to } \\
\text { commercial and } \\
\text { social/political } \\
\text { opportunities }\end{array}$ \\
\hline
\end{tabular}




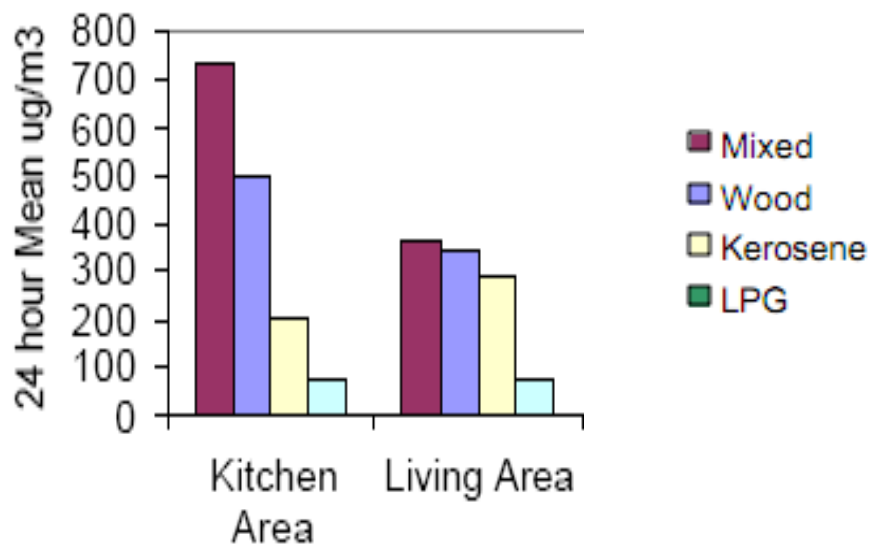

Source: Adapted from World Bank (2002)

Figure 1: Indoor Air Pollution due to different fuels 


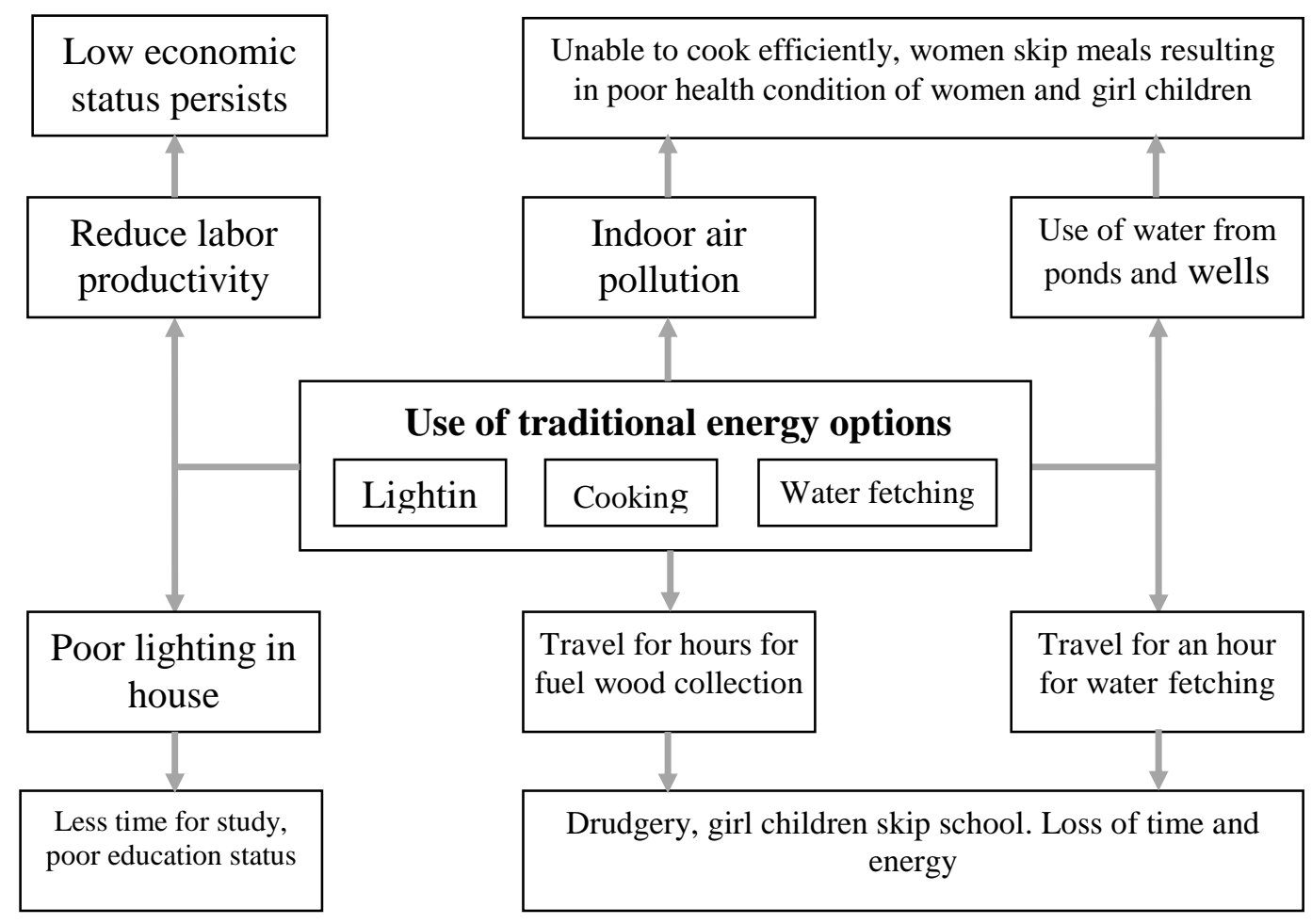

Figure 2: Cause and effect relationship of traditional energy use 


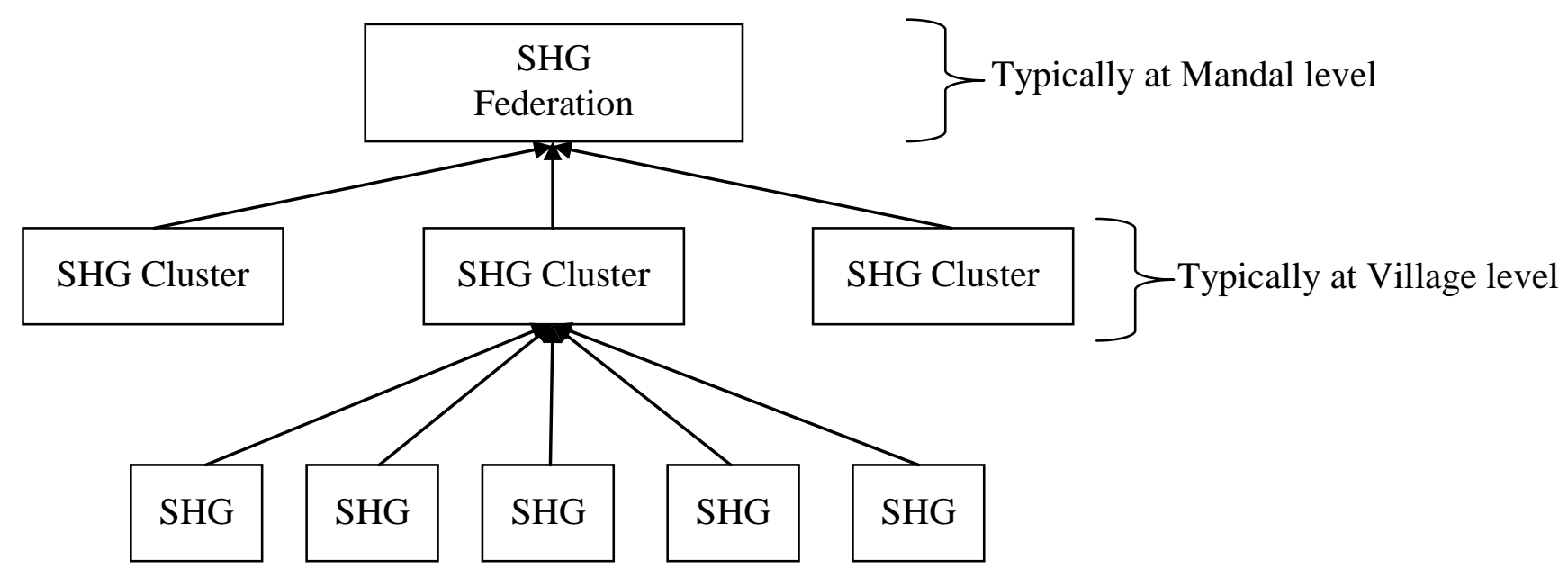

Source: Adapted from Reddy and Manak (2005)

Figure 3: SHG Structure 


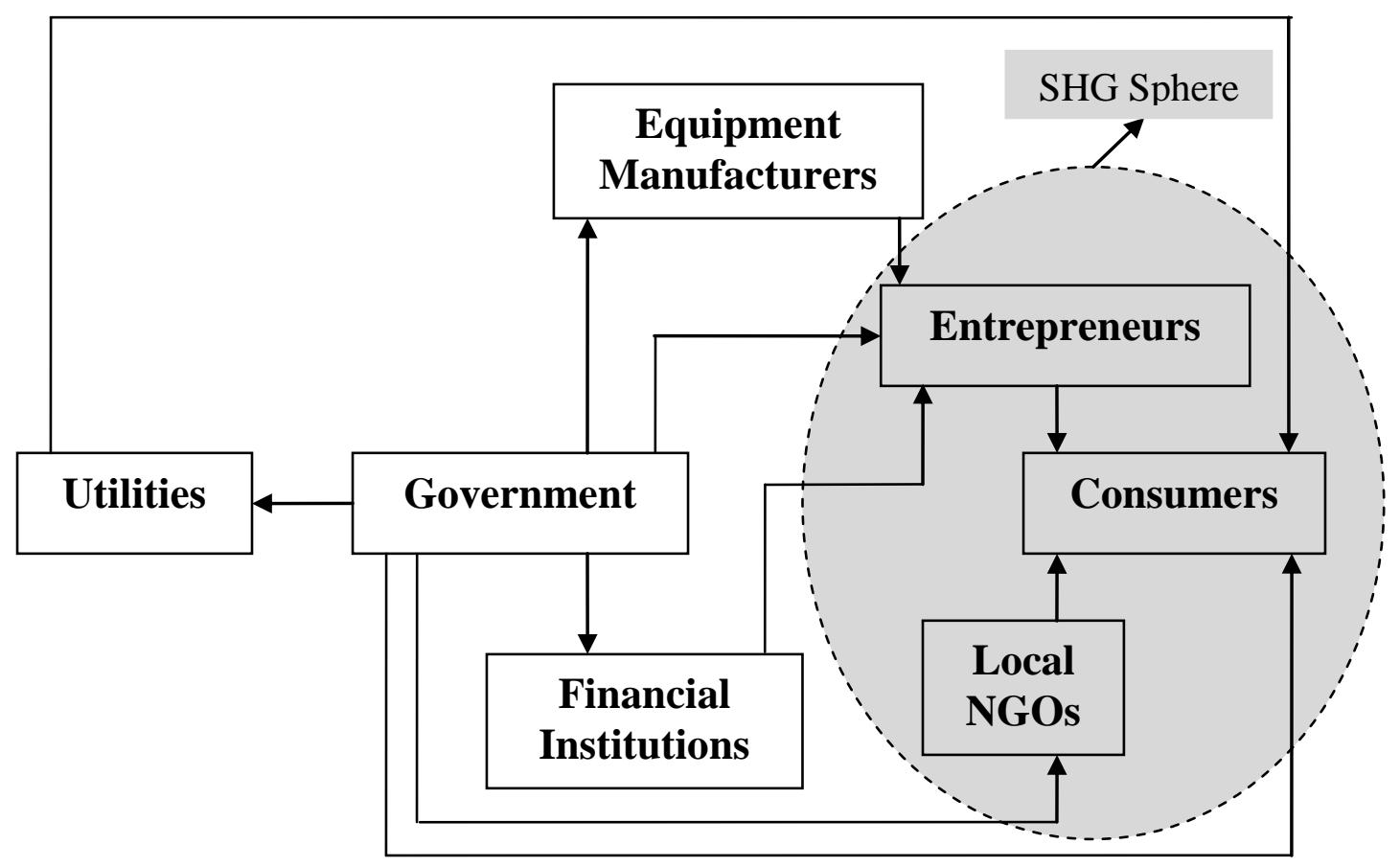

Source: Adapted from Reddy et al (2009)

Figure 4: Empower model with SHG Sphere 